\title{
Application of sugarcane bagasse for passive anaerobic biotreatment of sulphate rich wastewaters
}

\author{
Ali Hussain · Javed Iqbal Qazi
}

Received: 1 March 2014 / Accepted: 21 July 2014/Published online: 9 September 2014

(C) The Author(s) 2014. This article is published with open access at Springerlink.com

\begin{abstract}
Biological treatment of sulphate-rich wastewaters employing dissimilatory sulphate reducing bacteria as remedial agents is an attractive technique and has gained importance in the last few years. Industrial effluents enriched with sulphates are generally deficient in electron donors. And thus cannot be treated biologically without supplementation of carbon through an external source. For scalable operations, however, the carbon source must not be expensive. In this context, present study reports the efficiency of biological sulphate reduction using sugarcane bagasse as a cost-effective carbon source. An average $0.00391 \pm 0.001 \mathrm{gL}^{-1} \mathrm{day}^{-1}\left(3.91 \mathrm{mgL}^{-1} \mathrm{day}^{-1}\right)$ sulphate reduction was observed reaching maximally to $0.00466 \pm$ $0.001 \mathrm{gL}^{-1} \mathrm{day}^{-1}\left(4.66 \mathrm{mgL}^{-1} \mathrm{day}^{-1}\right)$ while employing Desulfovibrio fructosovorans-HAQ2 and Desulfovibrio piger-HAQ6 in a 60-day trial of anaerobic incubation using sugarcane bagasse as growth substrate. These findings will be helpful in developing economical bioremediation processes tending to operate for a longer period of time to reduce sulphate contents of contaminated waters.
\end{abstract}

Keywords Carbon source - Economical bioremediation . Electron donor - Passive treatment - Sugarcane bagasse . Sulphate reduction

\section{Introduction}

Several bioremediation processes including decontamination of acid mine drainage and sulphate rich waste waters

\footnotetext{
A. Hussain $(\bowtie) \cdot$ J. I. Qazi

Department of Zoology, University of the Punjab, Lahore 54590, Pakistan

e-mail: alihussainpu@yahoo.com
}

using sulphate-reducing bacteria (SRB) have been practiced much in the last decade (Johnson and Hallberg 2005; Neculita et al. 2007; Martins et al. 2009; Hussain and Qazi 2012). SRB collectively make a group of obligatory anaerobes exhibiting diverse morphological as well as physiological characteristics and occupy a wide range of habitats among terrestrial, sub-terrestrial and aquatic ecosystems (Willis et al. 1997). They may be autotrophic or heterotrophic with assimilatory or dissimilatory types of metabolisms. Both dissimilatory autotrophs and heterotrophs use sulphate $\left(\mathrm{SO}_{4}{ }^{2-}\right)$ as terminal electron acceptor. The former metabolize $\mathrm{CO}_{2}$ and the latter utilize multifarious energy-rich organic compounds as carbon sources/ electron donors while generating sulfide (Pfennig et al. 1981; Lens and Kuennen 2001; Rabus et al. 2006; Martins et al. 2009). In various bioremediation processes based on the use of dissimilatory SRB, this biogenic sulfide reacts vigorously with dissolved metals present in the wastewaters forming insoluble precipitates of metal sulfides thus reducing the concentrations of metals and sulphates simultaneously (Costa and Duarte 2005; Vega-López et al. 2007; Martins et al. 2009).

Biological sulphate reduction is an energy-intensive process, thus, an efficient energy-rich carbon source is required (Barnes 1998). It is well known that SRB generally prefer simple low-molecular weight substrates such as sodium lactate and ethanol as energy sources. But being too much expensive, these cannot be used in bioremediation processes at large scales (Postgate 1984; Barnes 1998; El Bayoumy et al. 1999; Tsukamoto et al. 2004; Huisman et al. 2006). However, utilization of various environmental contaminants for instance, halogenated compounds and petroleum hydrocarbons' constituents has been reported by researchers (Fauque et al. 1991; Hao et al. 1996; Harms et al. 1999; Morasch et al. 2004). In addition, several 
different kinds of organic wastes have been employed in bioremediation processes using SRB and include animal manure, leaf mulch, molasses, mushroom compost, sawdust, sewage sludge, vegetal compost, watermelon rind, whey, wood chips and other agricultural wastes (Dvorak et al. 1992; Hammack et al. 1994; Christensen et al. 1996; Waybrant et al. 1998; Annachhatre and Suktrakoolvait 2001; Costa and Duarte 2005; Coetser et al. 2006; Hussain and Qazi 2012; Hussain et al. 2014).

Selection of an economical and cost-effective growth substrate is of great significance in passive biotreatment processes. In most of the agricultural lands rice and wheat straw, rice husk and sugarcane bagasse are the key agricultural wastes. Of these wastes, sugarcane bagasse deserves special attention due to its abundant availability in almost all of the agricultural countries and competitive uses in many biotechnological processes especially as an ideal growth substrate for microbes for the production of value-added products such as bioethanol (Cardona et al. 2010), amino acids, enzymes, protein-rich animal feed and compounds of pharmaceutical importance (Parameswaran 2009). Application of sugarcane bagasse for various bioremediation processes is also well known (Krishnani et al. 2006; Garg et al. 2007; Sharma and Kaur 2011; Mukherjee et al. 2014). Sugarcane crop and its principal as well as byproducts are cheaper because the manual labour is far more cheaper and easily available whenever and wherever it is needed in developing countries, especially in Pakistan compared to developed and richer countries. Therefore, the cost-limiting factors such as collection, transportation and processing of sugarcane bagasse reinforce its utility in different biotechnological processes for such developing agricultural lands. Pakistan produces more than 12 million tons of the bagasse annually (Dawn News 2012). Currently, sugarcane bagasse is either used as fuel for electricity generation or contributes to environmental pollution in Pakistan (Ahmad and Qazi 2014). Utilization of sugarcane bagasse as growth substrate in biological sulphate reduction processes will lead to the concomitant treatment of both the organic and inorganic wastes. Keeping in view these facts, the present study was designed to investigate the efficiency of biological sulphate reduction using sugarcane bagasse as a cost effective and frequently available carbon source.

\section{Materials and methods}

Isolation of SRB from wastewater

Wastewater samples were collected from the bed of a leading domestic and industrial effluents carrying channel (Hadiara drain) in Lahore, Pakistan and processed for SRB culture enrichment as in Hussain and Qazi (2012) using
Postgate B medium (Postgate 1984). The composition of Postgate B medium is shown in Table 1. Sulfidogenic bacterial growth was assessed through the formation of black precipitates and production of rotten egg smell of $\mathrm{H}_{2} \mathrm{~S}$ which was checked by withdrawing and smelling the gas using a sterilized disposable syringe. The enrichments made thus were used to isolate pure cultures of SRB as described by Postgate (1984). Following the procedure, eight sulfidogenic bacterial strains were isolated and pure cultured.

\section{Batch experiments}

These were performed in triplicates in serum bottles of $120 \mathrm{~mL}$ capacity using artificially prepared sulphate-rich

Table 1 Compositions of various media used in this study

\begin{tabular}{|c|c|c|}
\hline Medium & Ingredients & $\begin{array}{l}\text { Quantity } \\
\left(\mathrm{gL}^{-1}\right)\end{array}$ \\
\hline \multirow[t]{10}{*}{ Postgate B medium } & $\mathrm{KH}_{2} \mathrm{PO}_{4}$ & 0.5 \\
\hline & $\mathrm{NH}_{4} \mathrm{Cl}$ & 1 \\
\hline & $\mathrm{CaSO}_{4}$ & 1 \\
\hline & $\mathrm{MgSO}_{4} \cdot 7 \mathrm{H}_{2} 0$ & 2 \\
\hline & $\mathrm{FeSO}_{4} \cdot 7 \mathrm{H}_{2} \mathrm{O}$ & 0.5 \\
\hline & Sodium lactate & $3.5 \mathrm{~mL}$ \\
\hline & Yeast extract & 1 \\
\hline & Ascorbic acid & 0.1 \\
\hline & $\begin{array}{l}\text { Thioglycollic } \\
\text { acid }\end{array}$ & $0.1 \mathrm{~mL}$ \\
\hline & $\mathrm{pH}: 7.0-7.5$ & \\
\hline \multirow[t]{12}{*}{ Postgate E medium } & $\mathrm{KH}_{2} \mathrm{PO}_{4}$ & 0.5 \\
\hline & $\mathrm{NH}_{4} \mathrm{Cl}$ & 1 \\
\hline & $\mathrm{Na}_{2} \mathrm{SO}_{4}$ & 1 \\
\hline & $\mathrm{CaCl}_{2} \cdot 6 \mathrm{H}_{2} \mathrm{O}$ & 1 \\
\hline & $\mathrm{MgCl}_{2} .7 \mathrm{H}_{2} \mathrm{O}$ & 2 \\
\hline & $\mathrm{FeSO}_{4} \cdot 7 \mathrm{H}_{2} \mathrm{O}$ & 0.5 \\
\hline & Sodium lactate & $3.5 \mathrm{~mL}$ \\
\hline & Yeast extract & 1 \\
\hline & Ascorbic acid & 0.1 \\
\hline & $\begin{array}{l}\text { Thioglycollic } \\
\text { acid }\end{array}$ & $0.1 \mathrm{~mL}$ \\
\hline & Agar & 15 \\
\hline & pH: 7.6 & \\
\hline \multirow{7}{*}{$\begin{array}{l}\text { Modified Postgate growth } \\
\text { medium }\end{array}$} & $\mathrm{NH}_{4} \mathrm{Cl}$ & 2 \\
\hline & $\mathrm{CaCl}_{2} \cdot 6 \mathrm{H}_{2} \mathrm{O}$ & 0.06 \\
\hline & $\mathrm{Na}_{2} \mathrm{SO}_{4}$ & 2 \\
\hline & $\mathrm{FeSO}_{4} \cdot 7 \mathrm{H}_{2} \mathrm{O}$ & 0.005 \\
\hline & Organic waste & $2 \%$ \\
\hline & Yeast extract & 0.1 \\
\hline & $\begin{array}{l}\text { Sodium citrate } \\
\mathrm{pH}: 7.0 \pm 0.5\end{array}$ & 0.3 \\
\hline
\end{tabular}


wastewater which was actually a modification of Postgate growth medium and comprised of sulphate $(2 \mathrm{~g} / \mathrm{L})$ and $2 \%$ fine powder of sugarcane bagasse $(w / v)$. Detailed composition of modified Postgate growth medium is shown in Table 1. Sodium lactate is the most widely used carbon source for cultivating SRB (Postgate 1984; Barnes 1998) and hence was employed in the control experiments. The inoculum size used was $5 \%(\mathrm{v} / \mathrm{v})$ harbouring around $1.7 \times 10^{6}$ colony forming units (C.F.U.)/mL. $\mathrm{pH}$ of the medium was adjusted to 7.0 for each experiment. Diffusion of oxygen in inoculated media was prevented by adding a layer of autoclaved liquid paraffin (about 3-5 $\mathrm{mm}$ thick). The inoculated bottles were sealed with fine rubber stoppers and aluminium crimps and incubated at $30{ }^{\circ} \mathrm{C}$ for 60 days.

Periodic analysis of various parameters

Periodically (after every 10 days), $5 \mathrm{~mL}$ samples were withdrawn with the help of a sterilized syringe and filtered using a fine quality filter paper (Whatman, Cat No. 1001917, England). $\mathrm{pH}, \mathrm{SO}_{4}{ }^{2-}$ and C.F.U./mL were analyzed in each experiment. $\mathrm{pH}$ was measured with the help of a digital $\mathrm{pH}$ meter (InoLab, $\mathrm{pH} 7110$ ), while, $\mathrm{SO}_{4}{ }^{2-}$ was estimated after Cha et al. (1999). The bacterial C.F.U. were estimated by cultivating $0.2 \mu \mathrm{L}$ of a culture in Postgate $\mathrm{E}$ medium (Postgate 1984). The composition of this medium is provided in Table 1 . The embedded black colonies were then counted after 5 days incubation at $30{ }^{\circ} \mathrm{C}$.

\section{Statistical analysis}

Statistically the data were analysed using GLM procedures and mean values were compared using Duncan's Multiple Range test with the help of SAS 9.1. Differences between mean values will be considered significant at $P<0.05$.

Genotypic characterization of the selected bacterial isolates

As present study reports sulphate reduction potentials of eight sulfidogenic bacterial isolates using sugarcane bagasse as growth substrate. In the initial screening based on sulphate reduction, the isolates which appeared a little bit different in terms of prodigious growth and better sulphate reduction performances were selected for genotypic characterization. For characterization of bacterial isolates at the molecular level, total genomic DNA was extracted from freshly grown cells of the selected bacterial isolates in Postgate B medium after Martins et al. (2009). Universal primers 27f (5'-AGAGTTTGATCMTGGCTCAG-3') and 1492r (5'-GGTTACCTTGTTACGACTT-3') were used to amplify $16 \mathrm{~S}$ rRNA gene. PCR was performed in $50 \mu \mathrm{L}$ total reaction volume (DNA extract, $5 \mu \mathrm{L} ; \mathrm{MgCl}_{2}$ $(25 \mathrm{mM}), 5 \mu \mathrm{L}$; dNTPs $(1 \mathrm{mM}), 5 \mu \mathrm{L}$; forward and reverse primers $(5 \mathrm{pmol}), 5 \mu \mathrm{L}$ of each; DNA Taq polymerase, $2 \mathrm{U} / \mathrm{mL}$; 1X Taq buffer, $5 \mu \mathrm{L}$; DNA free water, $18 \mu \mathrm{L}$ ). PCR amplification was carried out in a thermal cycler (Hamburg 22331, Germany) with a denaturation cycle for $3 \mathrm{~min}$ at $94{ }^{\circ} \mathrm{C}$ following 35 cycles of denaturation for $30 \mathrm{~s}$ at $95{ }^{\circ} \mathrm{C}$, annealing step of $2 \mathrm{~min}$ at $60{ }^{\circ} \mathrm{C}$ and $1 \mathrm{~min}$ extension at $72{ }^{\circ} \mathrm{C}$ with a final extension step of $30 \mathrm{~min}$ at $72{ }^{\circ} \mathrm{C}$. The PCR product obtained in this way was separated on $1 \%$ agarose gel stained with ethedium bromide in TAE buffer by electrophoresis. Amplified bands of $1.5 \mathrm{~kb}$ were visualized under UV (Gel Doc, Bio-Rad Laboratories, USA) and excised for purification using Gene Purification Kit (Fermentas) following the manufacturer instructions. The amplicons were then got sequenced using Big Dye Terminator v3.1 cycle sequencing ready reactions (Macrogen, Korea) at the DNA Sequencing Facility, Korea. 16S rRNA gene sequences were assembled with phrap (version 0.990319). Homology searches were performed using BLAST (http://www.ncbi.nlm.nih.gov/BLAST/). The 16S rDNA sequences determined in this way were submitted to GenBank for obtaining accession numbers.

\section{Results and discussion}

Genotypic characterization of the isolates, obtained in this study revealed that these isolates belonged to genus Desulfovibrio. Prevalence and dominance of Desulfovibrio genus in sulphate rich and anaerobic environments is best studied (Dar et al. 2005; Martins et al. 2009). Following the BLAST results the bacteria were identified as Desulfovibrio fructosovorans and Desulfovibrio piger. The GenBank has allotted accession numbers (KF536741 and KF536745, respectively) for these sequences. The growth patterns and sulphate reducing trends of all the isolates appeared very less variable throughout in this study.

Sulphates reduction rates remained comparatively higher in the first halves (between 10 to 30 days) and became gradually lower in the second halves (between 40 to 60 days) of observational periods (Fig. 1). Martins et al. (2009) have reported similar pattern of sulphate reduction during the assessment of food industry wastes as carbon sources in biological sulphate reduction processes. In spite of efficient sulphate reduction performances in the first halves, all the isolates showed extended lag phases showing negligible growth in the initial 10 days of anaerobic incubation periods (Fig. 2). SRB necessarily require longer lag periods to get acclimated to the more complex organic carbon sources (Beaulieu et al. 2000). Sugarcane bagasse is a heterogeneous mixture of simple and complex carbon polymers as presented in Table 2 . Longevity of lag phases 


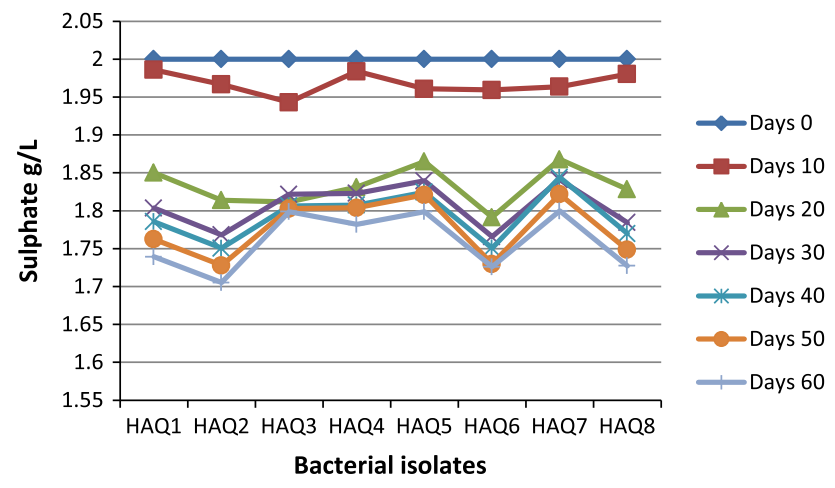

Fig. 1 Sulphate reduction trend shown by the SRB isolates using sugarcane bagasse as electron donor

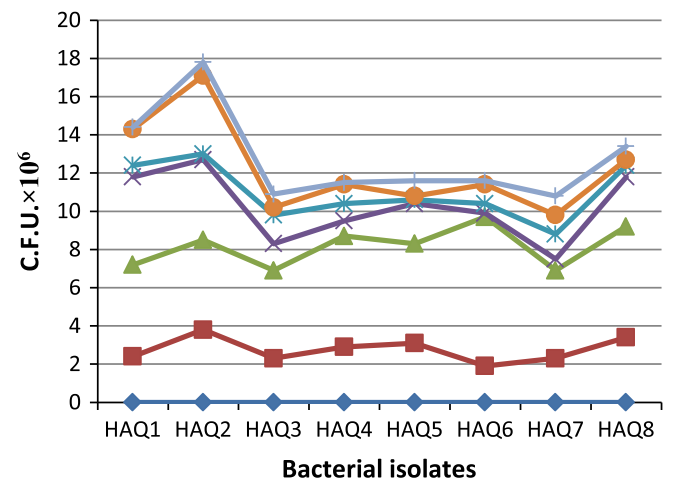

Fig. 2 Sulfidogenic bacterial growth pattern using sugarcane bagasse as carbon source

might be attributed to the acclimatization periods needed for SRB to utilize media containing complex carbon source following the induction and synthesis of proper enzyme system.

Once the bacterial growth became established in the presence of this complex substrate, sulphate reduction rates rose quickly to their peak values (between 10 to 20 days), dropped to their lower levels (from 20th day onwards) and gradually reduced to almost zero at the end of incubation periods (Fig. 1; Table 3). The earlier rise in sulphate reduction rates was probably due to consumption of frequently available simpler molecules in the primary stages of incubation. During the secondary stages of incubation, simple molecules might have been exhausted from the medium while promoting growth of SRB in the primary stages and, consequently, sulphate reduction rates decreased reasonably. The preference of SRB for simple organic molecules is a well reported phenomenon (Nagpal et al. 2000; Gibert et al. 2004; Tsukamoto et al. 2004; Zagury et al. 2006). When the SRB started to utilize this complex polymeric substrate, again increments in growth as well as sulphate reductions were recorded (Figs. 1, 2). For the complex nutrient media containing soluble as well as complex carbon sources, the process of diauxy is well
Table 2 Physicochemical and elemental analysis of sugarcane bagasse

\begin{tabular}{|c|c|c|}
\hline Content & $\begin{array}{l}\text { Percent }(\mathrm{w} / \mathrm{w}) \\
\text { on dry basis }\end{array}$ & Reference \\
\hline Cellulose & $40-60$ & McKendry (2002) \\
\hline Hemicellulose & $20-40$ & \\
\hline Lignin & $10-25$ & \\
\hline Total sugars & $13-18$ & Irfan et al. (2011) \\
\hline Reducing sugars & 8.02 & \\
\hline Crude fiber & 45.61 & Olagunju et al. (2014) \\
\hline Crude proteins & 3.3 & \\
\hline Lipid & 2.01 & \\
\hline Volatile matter & 84.83 & Das et al. (2004) \\
\hline Fixed carbon & 13.28 & \\
\hline Ash & 1.89 & \\
\hline $\mathrm{C}$ & 56.32 & \\
\hline $\mathrm{H}$ & 7.82 & \\
\hline $\mathrm{N}$ & 0.89 & \\
\hline $\mathrm{O}$ & 27.54 & \\
\hline $\mathrm{Na}$ & 0.012 & \\
\hline $\mathrm{K}$ & 0.175 & \\
\hline $\mathrm{Ca}$ & 0.087 & \\
\hline $\mathrm{Mg}$ & 0.437 & \\
\hline $\mathrm{Al}$ & 0.003 & \\
\hline $\mathrm{Fe}$ & 0.004 & \\
\hline $\mathrm{Zn}$ & 0.001 & \\
\hline $\mathrm{Cr}$ & 0.004 & \\
\hline $\mathrm{Cu}$ & 0.001 & \\
\hline $\mathrm{Mn}$ & 0.141 & \\
\hline $\mathrm{P}$ & 0.014 & \\
\hline $\mathrm{Si}$ & 0.911 & \\
\hline S & 0.042 & \\
\hline
\end{tabular}

$\mathrm{C}, \mathrm{H}, \mathrm{N}$ and $\mathrm{O}$ represent weight $(\%)$ on dry basis by difference

known (Crueger and Crueger 2005). These findings were consistent with those of Hussain and Qazi (2012) who reported similar results while studying the effectiveness of watermelon rind as carbon source in biological sulphate reduction.

In control experiments, $100 \%$ sulphate reduction was observed when sodium lactate was used as electron donor. The total sulphate was reduced in the first 10 days of incubation. This efficient sulphate reduction was most probably due to simplicity of the lactate molecules and neutral $\mathrm{pH}$ of the media as have been reported earlier (Martins et al. 2009; Singh et al. 2011).

An average $0.00391 \pm 0.001 \mathrm{gL}^{-1} \mathrm{day}^{-1}\left(3.91 \mathrm{mgL}^{-1}\right.$ day $^{-1}$ ) sulphate reduction was observed reaching maximally to $0.00466 \pm 0.001 \mathrm{gL}^{-1}$ day $^{-1}\left(4.66 \mathrm{mgL}^{-1} \mathrm{day}^{-1}\right)$ while employing Desulfovibrio fructosovorans-HAQ2 and Desulfovibrio piger-HAQ6 using sugarcane bagasse as growth substrate (Table 4). An increased rate of sulphate reduction 
Table 3 Pattern of biological sulphate reduction following periodic incubation of 10 days using sugarcane bagasse as growth substrate

\begin{tabular}{|c|c|c|c|c|c|c|c|}
\hline \multirow[t]{2}{*}{ Bacterial isolate } & \multicolumn{7}{|c|}{ Incubation period (days) } \\
\hline & 0 & 10 & 20 & 30 & 40 & 50 & 60 \\
\hline HAQ1 & $2.00 \pm 0.00$ & $1.99 \pm 0.01^{\mathrm{a}}$ & $1.85 \pm 0.02^{\mathrm{bc}}$ & $1.80 \pm 0.01^{\mathrm{cd}}$ & $1.77 \pm 0.01^{\mathrm{cd}}$ & $1.76 \pm 0.01^{\mathrm{c}}$ & $1.75 \pm 0.01^{\mathrm{b}}$ \\
\hline HAQ2 & $2.00 \pm 0.00$ & $1.97 \pm 0.02^{\mathrm{b}}$ & $1.81 \pm 0.00^{\mathrm{e}}$ & $1.77 \pm 0.01^{\mathrm{ef}}$ & $1.75 \pm 0.01^{\mathrm{de}}$ & $1.73 \pm 0.01^{\mathrm{d}}$ & $1.72 \pm 0.01^{\mathrm{bc}}$ \\
\hline HAQ3 & $2.00 \pm 0.00$ & $1.94 \pm 0.01^{\mathrm{c}}$ & $1.83 \pm 0.01^{\mathrm{de}}$ & $1.82 \pm 0.01^{\mathrm{bc}}$ & $1.81 \pm 0.01^{\mathrm{b}}$ & $1.80 \pm 0.01^{\mathrm{b}}$ & $1.80 \pm 0.01^{\mathrm{a}}$ \\
\hline HAQ4 & $2.00 \pm 0.00$ & $1.98 \pm 0.02^{\mathrm{a}}$ & $1.84 \pm 0.01^{\mathrm{cd}}$ & $1.82 \pm 0.01^{\mathrm{abc}}$ & $1.81 \pm 0.01^{\mathrm{b}}$ & $1.80 \pm 0.01^{\mathrm{b}}$ & $1.78 \pm 0.01^{\mathrm{a}}$ \\
\hline HAQ5 & $2.00 \pm 0.00$ & $1.96 \pm 0.00^{\mathrm{b}}$ & $1.87 \pm 0.00^{\mathrm{ab}}$ & $1.84 \pm 0.00^{\mathrm{ab}}$ & $1.83 \pm 0.01^{\mathrm{ab}}$ & $1.82 \pm 0.01^{\mathrm{a}}$ & $1.80 \pm 0.01^{\mathrm{a}}$ \\
\hline HAQ6 & $2.00 \pm 0.00$ & $1.96 \pm 0.01^{\mathrm{b}}$ & $1.79 \pm 0.00^{\mathrm{f}}$ & $1.77 \pm 0.01^{\mathrm{ef}}$ & $1.75 \pm 0.01^{\mathrm{de}}$ & $1.73 \pm 0.01^{\mathrm{d}}$ & $1.72 \pm 0.01^{\mathrm{bc}}$ \\
\hline HAQ7 & $2.00 \pm 0.00$ & $1.96 \pm 0.01^{\mathrm{b}}$ & $1.87 \pm 0.00^{\mathrm{a}}$ & $1.85 \pm 0.01^{\mathrm{a}}$ & $1.84 \pm 0.01^{\mathrm{a}}$ & $1.82 \pm 0.01^{\mathrm{a}}$ & $1.80 \pm 0.01^{\mathrm{a}}$ \\
\hline HAQ8 & $2.00 \pm 0.00$ & $1.98 \pm 0.03^{\mathrm{a}}$ & $1.83 \pm 0.01^{\mathrm{de}}$ & $1.78 \pm 0.02^{\mathrm{de}}$ & $1.77 \pm 0.01^{\mathrm{cd}}$ & $1.75 \pm 0.01^{\mathrm{c}}$ & $1.75 \pm 0.01^{\mathrm{b}}$ \\
\hline
\end{tabular}

Values represent sulphate concentration $(\mathrm{g} / \mathrm{L})$ and are mean \pm S.E. of three replicates. Those not sharing a common alphabet within a respective column are significantly different from each other

Single factor analysis of variance at $P<0.05$

Table 4 Overall sulphate reduction rates of SRB isolates after completion of anaerobic incubation

\begin{tabular}{lll}
\hline $\begin{array}{l}\text { Bacterial } \\
\text { isolate }\end{array}$ & $\begin{array}{l}\text { Total } \mathrm{SO}_{4}{ }^{2-} \text { reduction } \\
\left(\mathrm{gL}^{-1}\right)\end{array}$ & $\begin{array}{l}\mathrm{SO}_{4}{ }^{2-} \text { reduction rate/day } \\
\left(\mathrm{gL}^{-1} \mathrm{day}^{-1}\right)\end{array}$ \\
\hline HAQ1 & $0.25 \pm 0.01$ & $0.00416 \pm 0.0001$ \\
HAQ2 & $0.28 \pm 0.01$ & $0.00466 \pm 0.0001$ \\
HAQ3 & $0.20 \pm 0.01$ & $0.00333 \pm 0.0001$ \\
HAQ4 & $0.22 \pm 0.01$ & $0.00366 \pm 0.0001$ \\
HAQ5 & $0.20 \pm 0.01$ & $0.00333 \pm 0.0001$ \\
HAQ6 & $0.28 \pm 0.01$ & $0.00466 \pm 0.0001$ \\
HAQ7 & $0.20 \pm 0.01$ & $0.00333 \pm 0.0001$ \\
HAQ8 & $0.25 \pm 0.01$ & $0.00416 \pm 0.0001$ \\
\hline
\end{tabular}

Values are mean \pm S.E. of three replicates

in the latter cases might be due to preference of this bacterial species particularly for consuming reducing sugars present in the growth substrate as reported earlier by Ollivier et al. (1988).

Sulphate reduction rates of all the isolates remained the same $\left(0.0333 \mathrm{gL}^{-1} \mathrm{day}^{-1}\right)$ as $100 \%$ reductions were noticed in all the cases. The much lower reduction in case of sugarcane bagasse seemed significant when the cost of these two carbon sources was compared. Per kilogram costs of sodium lactate and sugarcane bagasse are 800 and 0.05 (in US Dollars), respectively.

Sulphate reduction rates of the pure cultures of SRB remained, in general, at low profiles while utilizing the lingo-cellulosic substrate, leaving behind a significant fraction of non-degraded carbon (cellulosic) mass which could be utilized by SRB if these were used in mixed cultures. An implication of mixed cultures is advantageous in providing bacterial consortium that facilitate both the development of reducing conditions as well as utilization of complex nutritive substrates (Gibert et al. 2002).
Sulphate reduction rates can be enhanced using bioactivated bacterial consortia. According to Beaulieu et al. (2000) bioactivation of bacterial consortia with an easily available simple organic source (e.g. lactate) and then replacing it with any organic waste or a mixture of organic wastes can lead to better sulphate reduction rates. It is also noticeable that multiple organic wastes perform better than a single waste (Waybrant et al. 1998; Zagury et al. 2006).

An important benefit of partially degradable carbon source is that it provides carbon for a long-term run and in this way fulfils the basic need of passive biotreatment processes (Reisman et al. 2003). Further work is required to delineate sulphate reduction potential of bioactivated and/or mixed SRB cultures employing multiple organic wastes including the one reported here.

\section{Conclusion}

The availability, technical and economical viability of sugarcane bagasse and other similar lingo-cellulosic wastes (slowly biodegradable) in agricultural lands similar to Pakistan suggest these organic wastes as appropriate growth substrates for passive biotreatment of sulphate rich effluents/wastewaters than quite easily biodegradable but costly substrates. More better results can be obtained by diluting the wastewater to be treated. The efficiency of sulphate reduction can be enhanced further using mixed cultures of SRB as well as mixtures of different organic wastes. Thus, these aspects demand further studies in future.

Acknowledgments Financial support of Higher Education Commission, Pakistan for funding the first author under the "Indigenous Ph.D. 5000 Fellowship programme" is highly acknowledged. 
Open Access This article is distributed under the terms of the Creative Commons Attribution License which permits any use, distribution, and reproduction in any medium, provided the original author(s) and the source are credited.

\section{References}

Ahmad Q-A, Qazi JI (2014) Thermophilic fermentations of lignocellulosic substrates and economics of biofuels: prospects in Pakistan. Int J Energy Environ Eng 5:94. doi:10.1007/s40095014-0094-4

Annachhatre AP, Suktrakoolvait S (2001) Biological sulfate reducing using molasses as a carbon source. Water Environ Res $73: 118-126$

Barnes LJ (1998) Removal of heavy metals and sulphate from contaminated groundwater using sulphate-reducing bacteria: development of a commercial process. In: Sikdar SK, Irvine RL (eds) Bioremediation technologies. Lancaster, USA, pp 577-619

Beaulieu S, Zagury GJ, Deschênes L, Samson R (2000) Bioactivation and bioaugmentation of a passive reactor for acid mine drainage treatment. In: Singhal RK, Mehrotra AK (eds) Environmental issues and management of waste in energy and mineral production. Rotterdam, Netherlands, pp 533-537

Cardona CA, Quintero JA, Paz IC (2010) Production of bioethanol from sugarcane bagasse: status and perspectives. Bioresour Technol 101:4754-4766

Cha JM, Cha WS, Lee J-H (1999) Removal of organo-sulphur odour compounds by Thiobacillus novellus srm, sulphur-oxidizing bacteria. Process Biochem 34:659-665

Christensen B, Laake M, Lien T (1996) Treatment of acid mine water by sulphate reducing bacteria; results from a bench scale experiment. Water Res 30:1617-1624

Coetser S, Pulles W, Heath R, Cloete T (2006) Chemical characterization of organic electron donors for sulfate reduction for potential use in acid mine drainage treatment. Biodegradation 17:67-77

Costa MC, Duarte JC (2005) Bioremediation of acid mine drainage using acidic soil and organic wastes for promoting sulphatereducing bacteria activity on a column reactor. Water Air Soil Pollut 165:325-345

Crueger W, Crueger A (2005) Biotechnology: a textbook of industrial microbiology. Panima Publishing Corporation, New Delhi

Dar SA, Kuenen JG, Muyzer G (2005) Nested PCR-denaturing gradient gel electrophoresis approach to determine the diversity of sulfate-reducing bacteria in complex microbial communities. Appl Environ Microbiol 71:2325-2330

Das P, Ganesh A, Wangikar P (2004) Influence of pretreatment for deashing of sugarcane bagasse on pyrolysis products. Biomass Bioenergy 27:445-457

Dawn News (2012) Dawn News, Pakistan. http://x.dawn.com/2012/ 09/03/mills-for-new-policy-on-bagasse-fuelled-power-cogeneration. Accessed 12 August 2013

Dvorak DH, Hedin RS, Edenborn HM, Mclntire PE (1992) Treatment of metal-contaminated water using bacterial sulfate reduction: results from pilot-scale reactors. Biotechnol Bioeng 40:609-616

El Bayoumy MA, Bewtra JK, Ali HI, Biswas N (1999) Sulfide production by sulfate reducing bacteria with lactate as feed in an up flow anaerobic fixed film reactor. Water Air Soil Pollut 112:67-84

Fauque G, Legall J, Barton LL (1991) Sulfate-reducing and sulfurreducing bacteria. In: Shively JM, Barton LL (eds) Variations in autotrophic life. Academic, London, pp 271-337
Garg UK, Kaur MP, Garg VK, Sud D (2007) Removal of hexavalent chromium from aqueous solution by agricultural waste biomass. J Hazard Mater 140:60-68

Gibert O, De Pablo J, Cortina JL, Ayora C (2002) Treatment of acid mine drainage by sulphate-reducing bacteria using permeable reactive barriers: a review from laboratory to full-scale experiments. Rev Environ Sci Biotechnol 1:327-333

Gibert O, De Pablo J, Cortina JL, Ayora C (2004) Chemical characterization of natural organic substrates for biological mitigation of acid mine drainage. Water Res 38:4186-4196

Hammack TW, Edenborn HM, Dvorak DH (1994) Treatment of water from an open-pit copper mine using biogenic sulfide and lime stone: a feasibility study. Water Res 28:2321-2329

Hao OJ, Chen JM, Huang LJ, Buglass RL (1996) Sulfate-reducing bacteria. Crit Rev Environ Sci Technol 26:155-187

Harms G, Zengler K, Rabus R, Aeckersberg F, Minz D, RosselloMora R, Widdel F (1999) Anaerobic oxidation of $o$-xylene, $m$ xylene, and homologous alkylbenzenes by new types of sulfatereducing bacteria. Appl Environ Microbiol 65:999-1004

Huisman JL, Schouten G, Dijkman H (2006) Biotechnological solutions for the treatment of pickle liquors. In: Dutrizac J, Riveros PA (eds) Iron control technologies. Metallurgical Society, Montreal, pp 805-814

Hussain A, Qazi JI (2012) Biological sulphate reduction using watermelon rind as a carbon source. Biologia (Pakistan) 58:85-92

Hussain A, Shakir HA, Qazi JI (2014) Anaerobic biodegradation of sulphate employing animal manure as a cost effective growth substrate. J Anim Plant Sci 24:913-918

Irfan M, Syed Q, Abbas S, Sher MG, Baig S, Nadeem M (2011) FTIR and SEM analysis of thermo-chemical fractionated sugarcane bagasse. Turk J Biochem 36:322-328

Johnson DB, Hallberg KB (2005) Biogeochemistry of the compost bioreactor components of a composite acid mine drainage passive remediation system. Sci Total Environ 338:81-93

Krishnani KK, Parimala V, Gupta BP, Azad IS, Meng X, Abraham M (2006) Bagasse-assisted bioremediation of ammonia from shrimp farm wastewater. Water Environ Res 78:938-950

Lens PNL, Kuennen JG (2001) The biological sulfur cycle: novel opportunities for environmental biotechnology. Water Sci Technol 44:57-66

Martins M, Faleiro LM, Barros RJ, Veríssimo AR, Costa CM (2009) Biological sulphate reduction using food industry wastes as carbon sources. Biodegradation 20:559-567

McKendry P (2002) Energy production from biomass (part 1): overview of biomass. Bioresour Technol 83:37-46

Morasch B, Schink B, Tebbe CC, Meckenstock RU (2004) Degradation of $o$-xylene and $m$-xylene by a novel sulphate-reducer belonging to the genus Desulfotomaculum. Arch Microbiol 181:407-417

Mukherjee K, Saha R, Ghosh A, Ghosh SK, Maji PK, Saha B (2014) Surfactant-assisted bioremediation of hexavalent chromium by use of an aqueous extract of sugarcane bagasse. Res Chem Intermed 40:1727-1734

Nagpal S, Chuichulcherm S, Livingstone A, Peeva L (2000) Ethanol utilization by sulfate-reducing bacteria: an experimental and modeling study. Biotechnol Bioeng 70:533-543

Neculita CM, Zagury GJ, Bussie're B (2007) Passive treatment of acid mine drainage in bioreactors using sulphate reducing bacteria. J Environ Qual 36:1-16

Olagunju A, Muhammad A, Aimola IA, Abdullahi SA, Danhassan MS (2014) Effect of Lachnocladium spp. fermentation on nutritive value of pretreated sugarcane bagasse. Int J Mod Biol Med 5:24-32

Ollivier B, Cord-Ruwisch R, Hatchikian EC, Garcia JL (1988) Characterization of Desulfovibrio fructosovorans sp. nov. Arch Microbiol 149:447-450 
Parameswaran B (2009) Sugarcane bagasse. In: Nigam PS, Pandey A (eds) Biotechnology for agro-industrial residues utilisation. Springer, Berlin, pp 239-252

Pfennig N, Widdel F, Truper H (1981) The dissimilatory sulfatereducing bacteria. In: Mortimer PS, Heinz S, Truper HG, Balows A, Schelegel GH (eds) The prokaryotes: a handbook on habitats, isolation and identification of bacteria. Springer, Berlin, p 926

Postgate JR (1984) The sulfate-reducing bacteria. Cambridge University Press, Cambridge

Rabus R, Hansen TA, Widdel F (2006) Dissimilatory sulfate- and sulfur-reducing prokaryotes. In: Dworkin M, Falkow S, Rosenberg E, Schleifer KH, Stackebrandt E (eds) The prokaryotes, vol 2., Ecophysiology and biochemistrySpringer, Berlin, pp 659-768

Reisman DJ, Gusek JJ, Bishop M (2003) A pre treatability study to provide data for construction of a demonstration bioreactor. In: The proceedings of the 10th international conference on tailings and mine waste. pp 305-315

Sharma P, Kaur H (2011) Sugarcane bagasse for the removal of erythrosin B and methylene blue from aqueous waste. Appl Water Sci 1:135-145

Singh R, Kumar A, Kirrolia A, Kumar R, Yadav N, Bishnoi NR, Lohchab RK (2011) Removal of sulphate, COD and Cr(vi) in simulated and real wastewater by sulphate reducing bacteria enrichment in small bioreactor and FTIR study. Bioresour Technol 102:677-682

Tsukamoto TK, Killion HA, Miller GC (2004) Column experiments for microbiological treatment of acid mine drainage: lowtemperature, low $\mathrm{pH}$ and matrix investigations. Water Res 38:1405-1418

Vega-López A, Amora-Lazcano E, López-López E, Terrón O, ProalNágera JB (2007) Toxic effects of zinc on anaerobic microbiota from Zimapán Reservoir (Mexico). Anaerobe 13:65-73

Waybrant KR, Blowes DW, Ptacek CJ (1998) Selection of reactive mixtures for use in permeable reactive walls for treatment of mine drainage. Environ Sci Technol 32:1972-1979

Willis CL, Cummings JH, Neale G, Gibson GR (1997) Nutritional aspects of dissimilatory sulfate reduction in the human large intestine. Curr Microbiol 35:294-298

Zagury GJ, Kulnieks V, Neculita CM (2006) Characterization and reactivity assessment of organic substrates for sulphate-reducing bacteria in acid mine drainage treatment. Chemosphere 64:944-954 